\title{
A ÉTICA NO USO DE CÉLULAS TRONCO REVISÃO DE LITERATURA
}

\author{
ETHICS IN THE USE OF STEM CELLS \\ LITERATURE REVIEW \\ Danielle P. Matias', Amanda A. S. Otake', Felipe B. Mordhost', Francielle N. Viechineski', Jacques M. \\ C. Mantey', Rodrigo A. Guimarães' ${ }^{1}$ Gilberto Baroni*1 \\ Universidade Estadual de Ponta Grossa, Departamento de Medicina, Ponta Grossa, Paraná, Brasil \\ "Autor correspondente: Av. Vicente Machado 909 Ap. 71 Ponta Grossa-Paraná \\ Telefone - (42) 999720396 e-mail - gbaroninefro@gmail.com \\ ORCID http://orcid.org/0000-0002-1448-2181
}

\section{RESUMO}

No Brasil, a pesquisa com células-tronco embrionárias é disciplinada pela Lei n. ${ }^{\circ} 11.105$, de 24 de março de 2005, conhecida como Lei de Biossegurança. A utilização dessas células ainda acarreta princípios e paradigmas, apesar dos benefícios que a terapia celular pode trazer para a medicina. As grandes questões bioéticas nas pesquisas com as células-tronco recaem sobre o status do embrião humano, ou seja, a partir de que momento no desenvolvimento ele pode ser considerado moralmente uma pessoa. As teorias do surgimento da personalidade do embrião são arbitradas conforme julgamento moral, religioso, biológico ou legal. A dimensão jurídica da utilização dessas células é analisada através das diferentes legislações que regulam a matéria no Brasil e em outros países. As pesquisas com células-tronco embrionárias e células-tronco adultas demonstram que existem resultados práticos satisfatórios para fins terapêuticos. Com todo esse desenvolvimento biotecnológico, a bioética ainda não possui respostas para os dilemas dos limites da ciência, porém procura dar suporte para entendê-los.

Palavras-chave: Células-tronco. Bioética. Jurisprudência

\begin{abstract}
In Brazil, embryonic stem cell research is governed by the Law No. 11,105 of March 24, 2005, known as the Biosafety Law. Even so, the use of these cells still entails principles and paradigms, despite the benefits that cell therapy can bring to medicine. The major bioethical issues in stem cell research lie in the status of the human embryo, that is, from what point in its development it should be considered morally a person. Theories of the emergence of the embryo's personality are arbitrated according to moral, religious, biological or legal judgment. The legal dimension of the use of these cells is analyzed through the different laws that regulate the matter in Brazil and in other countries. Research on embryonic stem cells and adult stem cells shows that there are satisfactory practical results for therapeutic purposes. With all this biotechnological development, bioethics still has no answer to the dilemma of the limits of science, but seeks to provide some support to their understanding.
\end{abstract}

Keywords: Stem cells. Bioethics. Jurisprudence. 


\section{INTRODUÇÃO}

Os debates em torno das questões envolvendo o uso das células-tronco têm se tornado mais intensos nos últimos anos à medida que aumentam as pesquisas e, consequentemente, as descobertas de possibilidades terapêuticas das células-tronco, notadamente em países desenvolvidos (BARBOSA, 2013). No Brasil, a pesquisa com células-tronco embrionárias foi disciplinada pela Lei n. ${ }^{\circ} 11.105$, de 24 de março de 2005, do artigo 225 da Constituição Federal, conhecida como Lei de Biossegurança. $\mathrm{O}$ artigo $5^{\circ}$ da lei permite, com restrições, a manipulação de embriões humanos, produzidos por fertilização in vitro, para coleta de células-tronco. Posteriormente, foi regulamentada pelo Decreto n. ${ }^{\circ}$ 5.591, de 22 de novembro de 2005, que definiu como "embriões inviáveis" aqueles com alterações genéticas comprovadas que impedem o desenvolvimento por ausência de clivagem. Isso significa que a lei brasileira autorizou a pesquisa, preferencialmente, em embriões que não serão utilizados para fins reprodutivos após os procedimentos diagnósticos (DINIZ, 2009).

Desde então, várias iniciativas, em diferentes cenários, têm surgido com o intuito de apoiar, impedir ou controlar as pesquisas com células-tronco embrionárias e adultas. Isso tem acontecido paralelamente, confirmando ou refutando hipóteses levantadas por grupos de pesquisadores, que, além dos aspectos científicos, defendem valores e crenças que potencializam o grau de divergências e/ou consensos, não apenas no âmbito acadêmico, mas na sociedade como um todo, levando o questionamento sobre quais seriam as principais implicações bioéticas na pesquisa com células-tronco embrionárias. (BARBOSA, 2013).

Neste contexto, este trabalho teve como objetivo analisar as principais implicações bioéticas envolvidas na pesquisa com células-tronco embrionárias, no Brasil, considerando que existem diferentes posições quanto às possibilidades terapêuticas e, portanto, diferentes modos de ver o desenvolvimento destas pesquisas.

\section{MATERIAIS}

No presente trabalho, foi realizada uma revisão sistemática da literatura, enfocando nas abordagens éticas acerca das pesquisas com células-tronco embrionárias e adultas, sendo selecionados 17 artigos a partir do ano de 2001 a 2018, disponíveis nos bancos de dados da Biblioteca Virtual em Saúde (BVS), Scielo e Pubmed. Além disso, foram utilizadas uma tese de doutorado e uma de mestrado relacionadas ao tema, como também a Lei no 11.105 de 24 de março de 2005, do artigo 225 da Constituição Federal, conhecida como Lei de Biossegurança.

\section{RESULTADOS}

\section{O que são células-tronco?}

Células-tronco são células indiferenciadas. As principais características das células-tronco, tornando-as extremamente interessantes, são: sua capacidade de autorrenovação, ou seja, são capazes de se multiplicar, mantendo seu estado indiferenciado, proporcionando uma reposição ativa de sua população de maneira constante nos tecidos; e, mais interessante ainda, sua capacidade de se diferenciar em diversos tipos celulares (LEMISCHKA, 2005).

Controlando o ambiente circundante às células-tronco e ativando vias de sinalização, ocorre o acesso de diferentes tipos de células a partir de possíveis células-tronco (SCADDEN, 2006). Dada a especificidade como requisito das muitas estratégias utilizadas no desenvolvimento de medicamentos. 
Pequenas moléculas fornecem controle preciso sobre funções biológicas e podem ser reversíveis pela remoção do produto químico natural (CABRAL et al., 2016).

As células-tronco podem ser classificadas, segundo sua potencialidade, em totipotentes, pluripotentes ou multipotentes. As células capazes de gerar todos os tipos celulares embrionários e extraembrionários são chamadas de totipotentes, como o zigoto e o blastômero; as pluripotentes podem originar todas as células que formam um embrião (propriamente dito) e são provenientes da massa interna do blastocisto; as células que originam apenas um subgrupo de linhagens celulares são classificadas como mesenquimais, por exemplo, as células-tronco mesenquimais e neurais. Existem ainda células oligopotentes, capazes de gerar células mais restritas a uma linhagem do que as multipotentes, e as unipotentes, que originam apenas um único tipo celular maduro (WAGERS, 2004).

As células-tronco embrionárias dão origem a aproximadamente 220 tipos de células no ser humano adulto. Células-tronco embrionárias são mais versáteis em relação às células-tronco adultas multipotentes. A alta versatilidade e a capacidade ilimitada de autorrenovação colocaram um foco significativo em células-tronco embrionárias para o tratamento de doenças degenerativas, lesão e perda de tecido (ILIC, 2015). No entanto, como células-tronco embrionárias são derivadas da massa celular interna de embriões em estágio, a remoção dessas células-tronco resulta em inviabilidade do blastocisto, existindo preocupações éticas relacionadas ao isolamento (TREVOR, 2017).

\section{Usos terapêuticos das células-tronco}

O uso terapêutico das células-tronco se baseia principalmente nas células embrionárias. O potencial de diferenciação das células embrionárias tem sido cada vez mais conhecido tanto em testes com camundongos quanto em humanos (VERFAILLIE, 2002).

As células-tronco ganharam um uso muito importante no contexto da saúde pública ligada aos transplantes, já que a doação de órgão não consegue suprir toda a demanda de órgãos no país. Além disso, os transplantes são extremamente caros e dependem muito da estrutura de transporte disponível pelo sistema saúde. As células- tronco poderiam, então, ser multiplicadas no laboratório e induzidas para gerar um tipo celular específico com a capacidade de regenerar o órgão em questão (REVOLTELLA, 2007).

Vale ressaltar que a maioria das células-tronco adultas reside na medula óssea, estando, entre elas, as células-tronco hematopoiéticas (HSC) multipotentes, com capacidade de regenerar todo o sistema hematopoiético (BRYDER, 2006). Por conseguinte, o transplante terapêutico de medula óssea é utilizado há mais de 30 anos e mais de um milhão de pacientes que sofrem de diferentes doenças já foram tratados com transplante de medula óssea (M.O.) ou as células derivadas de M.O. mobilizadas. Ainda, há as células-tronco mesenquimais, que são definidas como o células estromais mesenquimais (MSC), que podem se diferenciar em células ósseas, cronócitos e adiposas (BIANCO, 2014).

Diversos estudos têm sugerido a capacidade dessas células em regenerarem o miocárdio pós-infarto (ORLIC, 2001). O mecanismo exato ainda não é conhecido. As células adultas têm sido amplamente testadas em doenças autoimunes, como lúpus eritematoso sistêmico (LES) e no diabetes do tipo I. No caso do diabetes, o objetivo é regenerar as células beta-pancreáticas produtoras de insulina, perdidas com a destruição crônica desde o início da doença (SEGERS, 2008).

As células-tronco embrionárias possuem reconhecida capacidade de diferenciação e proliferação, porém, é nesse ponto o seu primeiro empecilho. Seessa diferenciação e multiplicação não 
for controlada, ela poderá dar origem a tumores formados por vários tecidos diferentes. O segundo problema terapêutico das células-tronco embrionárias se baseia na compatibilidade biológica das células com todos os tipos de pacientes. Há uma chance de rejeição entre doador e receptor, o que não ocorre com células-tronco adultas, onde receptor e doador são a mesma pessoa (PEREIRA, 2008).

Apesar disso, as células-tronco embrionárias podem ser usadas para regenerar células da medula óssea, pancreáticas, alguns tipos específicos de cartilagem e músculos. Alguns experimentos destacam seu uso também na doença de Parkinson e Huntington (PEREIRA, 2008).

As células-tronco mesenquimais têm sido amplamente pesquisadas, principalmente as células do estroma do tecido adiposo. Elas possuem capacidade de diferenciação multipotente, ou seja, conseguem se diferenciar em diversos tipos de células, formando, assim, os órgãos. O seu uso terapêutico depende do local onde ocorre sua diferenciação (YARAK, 2010).

Outra linhagem de células-tronco em que há um avanço considerável na pesquisa terapêutica são as células pluripotentes induzidas (IPS). Essas células foram criadas com o objetivo de melhorar a plasticidade das células-tronco adultas por meio da transferência de núcleo e de reprogramação genética de células adultas, revertendo-as ao estágio embrionário. Seu estudo se dá mediante diversos marcadores específicos. Como as demais células-tronco, seu emprego tem sido discutido principalmente na rejeição de transplantes. Essa linhagem tem a capacidade de abordar a terapêutica dos transplantes de uma forma personalizada, já que a chance de rejeição seria extremamente baixa por se tratar de células reprogramadas do próprio receptor (TACHIBANA, 2014).

\section{Discussões éticas no uso de células-tronco}

$\mathrm{Na}$ virada do século XXI, as pesquisas com células-tronco ganharam força, com a promessa de uma medicina regenerativa, capaz de superar os desafios do adoecer e do envelhecimento. A capacidade dessas células de se transformar em diferentes tipos de tecidos conduziu à produção de expectativas em torno da possibilidade de ações terapêuticas dirigidas a diversas doenças. Há uma aposta em aplicações terapêuticas "sob medida", genética e imunologicamente direcionadas para cada pessoa, com o objetivo final de ampliar a eficácia de tratamentos celulares (ZORZANELLI et al., 2017).

A grande capacidade de potencial de diferenciação, a possibilidade de enxerto, efeitos imunossupressores e sua expansão em cultura levaram ao aumento do interesse clínico relativo ao uso das células-tronco mesenquimais, através de infusão intravenosa ou administração dirigida ao local de interesse, em numerosas situações patológicas. No caso de estudos em ensaios clínicos, bilhões de células mesenquimais são necessárias. A produção dessas células para este propósito necessita da observação e aderência às boas práticas de manufatura, para assegurar a liberação do "medicamento celular" de modo seguro, reprodutível e eficiente. Entretanto, não existem padrões para esta finalidade em ensaios clínicos. Todas as etapas do processo necessitam ainda ser definidas (SENSEBÉ, 2009).

Já foram realizados diversos experimentos com animais, os quais contribuíram para algumas áreas significativamente como: trabalhos na área da doença de Parkinson, de doenças neuromusculares, de diabetes tipo I e outras doenças (TAKEUCHI, 2006).

O debate inicial e controversa no uso de células troncos embrionárias remete ao estatuto do embrião. A confrontação de pensamentos se inicia a partir do momento que pessoas acreditam que o embrião é apenas um objeto, de direito e sem concessão de ser humano até uma certa parte de seu progresso, enquanto que uma outra parte das pessoas diz que o embrião é, sim, desde o início, 
um ser humano com direitos, pois já na fase inicial de seu progresso de um único ser com dignidades (GOMES, 2007).

De acordo com a biologia (a favor do uso de células-tronco embrionárias), a vida iniciaria após o surgimento do sistema nervoso (afinal, a falta de funcionalidade desse sistema nervoso define o que chamamos, hoje, de morte), portanto, o embrião seria no início, um aglomerado de células, sem tecidos e o início da vida seria predeterminado (de 2 a 3 dias após a fecundação). Além disso, há o argumento de que o embrião significa vida quando ele passa a ter a capacidade de reagir a estímulos uterinos e capacidade de sofrer, sentir e pensar. Utilizando esses ideais, pode-se negar a condição de pessoa a um embrião no estágio inicial (pelo menos na primeira semana) de desenvolvimento (LUNA, 2007).

Outras correntes de pensamento definem o embrião pelo local onde ele está, ou seja, ele é considerado uma vida apenas dentro do útero da mãe, quando está na placa de cultura ele é apenas uma vida em potencial. Ou seja, não haveria problema em utilizar esses embriões, já que eles não constituem uma vida em si (LUNA, 2007).

Os indivíduos que se manifestam ao contrário da utilização das células troncos, argumentam utilizando as questões éticas principalmente, e ressaltando que o embrião seria um ser humano individual. Além disso, muitos casais que realizaram/realizam a fertilização in vitro já consideram os embriões como futuros filhos, que podem vir a existir a qualquer momento e há a alegação de que pode haver riscos devido a uma possível formação de tumores (principalmente o teratoma), mutações e um diferente comportamento entre a célula in vivo e in vitro (que pode determinar estudos e condutas equivocados) (LUNA, 2007).

Há também a preocupação com a utilização excessiva dessa técnica, afinal, ela pode levar a um processo de desumanização por parte da sociedade, gerando ideais irreparáveis que desrespeitam a vida (inicialmente apenas nessa situação ocorre a permissão para "matar", mas posteriormente a sociedade pode internalizar isso como algo natural, e expandir esse "matar" a outras situações possíveis) (SEGRE, 2004).

Outro ponto citado pelos contrários ao uso de embriões é o fato de que, futuramente, se as pesquisas avançarem e se tornarem comuns, haverá a necessidade de uma produção exclusiva de embriões para o uso em experimentos, pois os embriões que já estariam nas clínicas não seriam suficientes para satisfazer a demanda das inúmeras pesquisas (LUNA, 2007).

No Brasil, a primeira Lei de Biossegurança tratava-se apenas da questão envolvendo pré-embriões humanos, fazendo com que o Ordenamento Jurídico Pátrio buscasse na Resolução 1.358/92 do Conselho Federal de Medicina amparo normativo necessário. Essa Resolução proíbe o descarte ou destruição dos embriões humanos criopreservados, mesmo com a manifestação expressa de casais sobre seu desinteresse pela preservação destes. A Resolução afirma ainda que o número ideal de oócitos e pré-embriões a serem transferidos para a receptora não deve ser superior a quatro, com o intuito de não aumentar os riscos já existentes de multiparidade. As clínicas, centros ou serviços podem criopreservar espermatozoides, óvulos e pré-embriões e esse número deverá ser comunicado aos pacientes, para que se decida quantos pré-embriões serão transferidos a fresco, devendo o excedente ser criopreservado, não podendo ser descartado ou destruído. No momento da criopreservação, os cônjuges ou companheiros devem expressar sua vontade, por escrito, quanto ao destino que será dado aos pré-embriões criopreservados, em caso de divórcio, doenças graves ou de falecimento de um deles ou de ambos, e quando desejam doá-los (OLIVEIRA, 2012). 
A Resolução 1.358/92 de Recomendação do Conselho Federal de Medicina não possui poder coercitivo (legal) que possa impor sua prática por meio de normas de Poder Legislativo. Fez-se, necessária, portanto, a elaboração de uma Lei que engloba todas as situações decorrentes da prática de pesquisa, utilizando-se de suas células-tronco (OLIVEIRA, 2012).

No ano de 2005, foi criada então a segunda Lei de Biossegurança (Lei n.11.105 de 24 de março de 2005), que regulamentou as pesquisas com células-tronco embrionárias para pesquisa e fins terapêuticos. Ela determina que essas células devem ser obtidas a partir de embriões derivados da fertilização in vitro (que não foram utilizados no procedimento) e esses embriões devem ser viáveis e terem ficado congelados por mais de três anos. Além disso, essa lei estabelece que os genitores do embrião têm que consentir com o processo e que deve haver a aprovação do projeto de pesquisa por um comitê de ética, e ainda, ela veta o comércio desse tipo de material para uso em pesquisas e proíbe a clonagem humana (BRASIL, 2005). A clonagem é proibida pois, nesse caso, o embrião clonado é criado e logo destruído, ou seja, mata-se uma vida para pesquisar e tentar salvar outras, não sendo considerado legal e ético (TAKEUCHI, 2006).

Esses experimentos e pesquisas com células-tronco embrionárias podem vir a expor novas opções de abordagem terapêutica para diversas doenças e trazer esperança ao paciente e sua família, os quais sofrem por não haver uma terapêutica totalmente eficiente em uso. No entanto, esse processo leva um tempo considerável e pode não resultar em nenhum benefício, sendo assim, pode abalar pacientes fragilizados que acreditam em uma cura imediata. Aqui evidencia-se o papel do médico, que deve esclarecer ao seu paciente que as pesquisas são importantes e podem trazer muitos benefícios, assim como elas podem não evidenciar benefício qualquer a um determinado caso (TAKEUCHI, 2006).

Outros países, como Índia e China, possibilitam a pesquisa com células-tronco embrionárias sem que haja um amplo debate de cunho legislativo tal como ocorreu no Brasil. Na China, as pesquisas na área de célula-tronco também contam com diretrizes éticas de pesquisa, sancionadas pelo Ministério da Ciência e Tecnologia e pelo Ministério da Saúde da China em 2003. A pesquisa em embriões humanos e a clonagem para fins terapêuticos é permitida, e o patrocínio é do Ministério Chinês da Ciência e Tecnologia, que tem planos de transformar o país num grande centro de pesquisa na área de células-tronco (MACHADO, 2015).

O Conselho da Europa segue uma legislação que protege o embrião, na qual é prescrito: "Não será permitido o uso de embriões, fetos ou seus tecidos para proveito ou fins de lucro". Ainda assim, os investimentos da indústria de cosméticos são elevados nas pesquisas com células embrionárias pela sua grande capacidade de reprodução celular, tendo como objetivo produzir produtos "derivados de embriões" para tentar satisfazer o oculto desejo de certas pessoas pela chamada "eterna juventude" (FILHO, 2018).

A África do Sul é o único país do continente africano que conta com uma legislação referente à pesquisa na área de célula-tronco. Contudo, a Lei Nacional de Saúde da África do Sul, no seu capítulo 8, que regulamenta as pesquisas na área de célula-tronco com "referência específica às disposições da Lei de Tecidos Humanos de 1983 e da Lei Nacional de Saúde de 2003", ainda não está em operação (MACHADO, 2015).

Nos EUA, o patenteamento de células-tronco é permitido, sendo que mais de 2.000 patentes foram concedidas entre os anos de 2005 e 2010, e existem mais de 100 corporações que detêm patentes voltadas ao uso e manuseio de terapia com células-tronco, sendo por esse motivo um dos países que mais publica sobre o assunto (SANTOS, 2018). 
É necessário que fique claro que a ciência e a pesquisa têm limites, portanto, nada deve ser prometido antes de ser comprovado. Um ganho gigantesco à comunidade futura será o avanço dessas pesquisas, trazendo terapêuticas e conhecimentos capazes de salvar cada vez mais vidas (TAKEUCHI, 2006).

Esses progressos científicos advindos das pesquisas, as quais apresentam pontos positivos e negativos, só serão aceitos ou não de acordo com as características culturais, crenças e conhecimentos de cada um, gerando discussões e opiniões divergentes, mas nenhuma considerada uma verdade absoluta (SEGRE, 2004).

\section{CONCLUSÃO}

São inegáveis os avanços e benefícios que as células-tronco trariam para a medicina, como demonstrado por diversos estudos, destacando-se as células-tronco embrionárias, pois apresentam maior capacidade de diferenciação e podem gerar qualquer outra célula do organismo (pluripotentes). No entanto, como elas estão presentes especialmente entre o $4^{\circ}$ e $5^{\circ}$ dia após a fecundação, muitas discussões éticas são levantadas em relação ao tema. Dentre elas, discute-se a necessidade de determinar o que seria a vida e qual o seu início, para assim poder determinar se o embrião com o qual será realizada a pesquisa já é uma vida em si, que pensa, sofre e sente. Além disso, evidencia-se a preocupação em utilizar de forma indiscriminada tal técnica, pois ela poderia levar à desumanização, tornando relativamente normal abreviar a vida. Devido a todas essas questões, viu-se a necessidade de criar uma legislação que regulamentasse essa prática, a Lei da Biossegurança. É importante reafirmar que o uso dessas células em pesquisas é uma prática que pode trazer novos inúmeros conhecimentos à sociedade, como tratamento e cura para várias doenças, além da melhora da qualidade de vida.

\section{REFERÊNCIAS}

BARBOSA, A. S. Implicações bioéticas na pesquisa com células-tronco embrionárias. Acta

Bioethica, v. 19, n. 1, p. 87-95, 2013.

BIANCO, P. "Mesenchymal" stem cells. Annu Rev Cell Dev Biol, v.30, p. 677-704, 2014.

BRASIL. Lei n. 11.105, de 24 de março de 2005 - Lei de Biossegurança. Regulamenta os incisos II, IV e $\vee$ do $\S 1^{\circ}$ do art. 225 da Constituição Federal, estabelece normas de segurança e mecanismos de fiscalização de atividades que envolvam organismos geneticamente modificados - OGM e seus derivados, cria o Conselho Nacional de Biossegurança - CNBS [...].

Diário Oficial da União, Brasília, DF., 24 mar. 2005.

BRYDER, D. et al. Hematopoietic stem cells: the paradigmatic tissue-specific stem cell. Am J Patho, V. 169, p. 338-346, 2006.

CABRAL, J. M. S. et al. Stem Cell Manufacturing. Amsterdam: The Netherlands, Elsevier, 2016.

DINIZ, D. Cenário internacional da pesquisa em células-tronco embrionárias. Revista de Saúde Pública, v. 43, n. 3, p. 541-547, 2009.

FILHO, D. M. O Mercado da Vida: Reflexões Sobre a Influência dos Interesses de mercado no Âmbito da Bioética. Revista Eletrônica Espaço Teológico, v. 12, n. 21, p. 42-52, 2018.

GOMES, D. Células-tronco embrionárias: implicações bioéticas e jurídicas. Bioethikos, v. 1, n. 2, p. 78-87, 2007. 
ILIC, D.; DEVITO, L. S. Human Embryonic and Induced Pluripotent Stem Cells in Clinical Trials. Br. Med. Bull, v.116, p.19-27, 2005.

LEMISCHKA, I.R. Stem cell biology: a view toward the future. Ann N Y Acad Sci., v. 1044, p. 132-138, 2005.

LUNA, N. Células-tronco: pesquisa básica em saúde, da ética à panacéia. Interface, Botucatu, v. 11, n. 23, p. 587-604. 2007.

MACHADO, R. N. Estrutura intelectual da literatura científica do Brasil e outros países dos BRICS: uma análise de cocitação de periódicos na área de célula-tronco. 2015. 364 f. Tese (Doutorado em Ciência da Informação) - Universidade Federal do Rio de Janeiro, Rio de Janeiro, 2015.

OLIVEIRA, G. P. T. C. Abordagens Hermenêuticas e Jurídicas no Tocante as Pesquisas em Célulastronco Embrionárias. Revista ESMAT, Palmas, v. 4, p. 127-156., 2012.

ORLIC, D. et al. Anversa P. Bone marrow cells regenerate infarcted myocardium. Nature, v. 410, p. 701-705, 2001.

PEREIRA, L. V. A importância do uso das células tronco para a saúde pública. Ciência \& Saúde Coletiva, v. 13, n. 1, p. 7-14, 2008.

REVOLTELLA, R. P.; PAPINI, S.; ROSELLINI, A.; MICHELINI, M. Epithelial stem cells of the eye surface.

Cell Proliferation, v. 40, n. 4, p. 445-461, 2007.

SANTOS, F. B. dos. Produção Tecnológica em Células-tronco: Características e Análise de Citação de Patentes Indexadas na Base de Dados Derwent Innovations Index. 2018. 107 f. Dissertação (Mestrado) - Universidade Federal do Rio Grande do Sul, Porto Alegre, 2018.

SCADDEN, D. T. The Stem-cell Niche as an Entity of Action. Nature, v. 441, p. 1075-1079, 2006.

SEGRE, M. A propósito da utilização de células-tronco embrionárias. Revista Estudos Avançados (USP), São Paulo, v. 18, n. 51, p. 257-262., 2004.

SEGERS, V. F. M.; LEE, R. T. Stem cell therapy for cardiac disease. Nature, v. 451, p. 937-942, 2008.

SENSEBÉ, L. Generation and characterization of mesenchymal stromal cells for clinical application. ISBT Science Series, v. 4, p. 31-36, 2009.

TACHIBANA, M.; AMATO, P.; SPARMAN, M.; GUTIERREZ, N. M.; TIPNNER- HEDGES, R. Human embryonic stem cells derived by somatic cell nuclear transfer. Cell, v. 153, n. 6, p. 1228-1238, 2014.

TAKEUCHI, C. A.; TANNURI, U. A polêmica da utilização de células-tronco embrionárias com fins terapêuticos. Revista da Associação Médica Brasileira, São Paulo, v. 52, n. 2, p.63. 2006.

TREVOR, C.J.; Directing Stem Cell Fate: The Synthetic Natural Product Connection. Chem. Rev., v. 117, p. 12052-12086, 2017.

VERFAILLIE, C. M. Adult stem cells: assessing the case for pluripotency. Trends in Cell Biology, v.12, p. 502-508, 2002.

WAGERS, A. J. Plasticity of adult stem cells. Cell, v. 116, p. 639-648, 2004.

YARAK, S. Células-tronco derivadas de tecido adiposo humano: desafios atuais e perspectivas clínicas. Anais Brasileiros de Dermatologia, v. 85, n. 5, p. 647-656, 2010.

ZORZANELLI, R. T. et al.Pesquisa com células-tronco no Brasil: a produção de um novo campo científico. Hist. ciênc. Saúde, Manguinhos, v.24, n. 1, p.129-144, jan.-mar. 2017. 